\title{
Effects of the size of sown seed on growth and yield of common bean cultivars of different seed sizes
}

\author{
Elvis Rodrigues Lima ${ }^{1}$, Aline Silva Santiago ${ }^{1}$, Adelson Paulo Araújo ${ }^{2 *}$ and Marcelo Grandi Teixeira ${ }^{3}$ \\ ${ }^{1}$ Departamento de Fitotecnia, Universidade Federal Rural do Rio de Janeiro, 23890-000, Seropédica, RJ, Brasil; ${ }^{2}$ Departamento de Solos, \\ Universidade Federal Rural do Rio de Janeiro, 23890-000, Seropédica, RJ, Brasil; ${ }^{3}$ Embrapa Agrobiologia, 23890-000, Seropédica, RJ, \\ Brasil; *Corresponding author: aparaujo@ufrrj.br. \\ Received: 14/02/2005, Accepted 30/05/2005
}

\begin{abstract}
A field experiment was conducted to evaluate the effects of planting different sizes of seed of the same cultivar on biomass accumulation and grain yield of common bean (Phaseolus vulgaris L.) cultivars of different seed sizes. A $6 \times 2$ split-plot factorial design with four replicates was employed, with six bean cultivars as main plots and two seed sizes (small and large, the latter twice as heavy as the former) of the same cultivar as subplots. Eight weekly samplings of biomass were performed, and yield components were measured at maturity. Large seeds increased the leaf area index and the shoot and root biomass of bean cultivars, particularly at the beginning of the growth cycle, but they did not affect the pod biomass. Improved growth associated with the large seed was more intense for erect than for prostrate cultivars. Plants originating from small seed presented a higher relative growth rate and net assimilation rate than plants from large seed. Large seed did not affect grain yield, but reduced the number of seeds per pod, increased the 100-seed mass, and reduced the harvest index. The results indicate that sowing larger seeds of a bean cultivar can improve early-season plant growth, which might be advantageous for crop establishment in stress environments. However, some compensatory effect, associated with delayed leaf senescence, higher net assimilation rate, or greater number of seeds per pod, allows plants originating from small seed to achieve similar grain yield. Lack of consistent effects of the seed size on grain yield indicate that the extra costs of sowing only the largest seed would not be profitable, but large seed resulted in larger grains at harvest which usually attain better market price.
\end{abstract}

Key words: Phaseolus vulgaris, genotype, growth analysis, leaf area, yield components.

Efeitos do tamanho da semente no crescimento e produção de cultivares de feijoeiro de diferentes tamanhos de semente: Desenvolveu-se um experimento de campo para avaliar os efeitos da variação do tamanho da semente da mesma cultivar na acumulação de biomassa e produção de grãos de cultivares de feijoeiro (Phaseolus vulgaris L.) de diferentes tamanhos de semente. Empregou-se um esquema fatorial $6 \times 2$ com quatro repetições, onde seis cultivares de feijoeiro constituíram as parcelas e, dois tamanhos de semente (pequeno e grande), as subparcelas. Efetuaram-se oito amostragens semanais de biomassa e mensuraram-se os componentes de produção na maturação. Sementes grandes aumentaram o índice de área foliar e a biomassa de parte aérea e raiz das cultivares de feijoeiro, particularmente no início do ciclo, mas não afetaram a massa de vagens. O estímulo ao crescimento ocasionado pelas sementes grandes foi mais intenso nas cultivares eretas do que nas prostradas. Plantas oriundas de sementes pequenas apresentaram maiores taxas de crescimento relativo e de assimilação líquida do que as oriundas de sementes grandes. Estas não afetaram a produção de grãos, mas reduziram o número de sementes por vagem e o índice de colheita, e levaram a massa de cem sementes. Os resultados indicaram que a semeadura de sementes grandes de uma cultivar de feijoeiro pode estimular o crescimento inicial do cultivo, o que pode ser vantajoso no estabelecimento da cultura sob condições de estresse. Entretanto, algum efeito compensatório, associado a atraso na senescência foliar, maior taxa de assimilação líquida, ou maior número de sementes por vagem, permite que plantas oriundas de sementes pequenas obtenham produção de grãos similar. Efeitos pouco consistentes do tamanho da semente no rendimento de grãos indicam que os custos adicionais da utilização apenas de sementes maiores podem não ser viáveis, mas as sementes grandes produziram maiores grãos na colheita, que, geralmente, atingem melhor preço de mercado.

Palavras-chave: Phaseolus vulgaris, análise de crescimento, área foliar, componentes de produção, feijão, genótipo. 


\section{INTRODUCTION}

Common bean (Phaseolus vulgaris L.) is an important source of protein and calories in human diets in tropical and subtropical developing countries, particularly in the Americas and in Eastern and Southern Africa (Laing et al., 1984). In view of the widely diverse cropping systems under which common bean is grown, commercial yields are very variable and often fall far below the genetic potential of the species (Graham and Ranalli, 1997). The use of grains for sowing, instead of selected seed, is one factor that contributes to such low commercial yields, since sowing seed of high quality can increase bean yield up to 40 \% (Embrapa, 1994).

Seed weight of common bean is genetically controlled, probably by few genes with a large phenotypic effect, and the domestication of the species has led to larger seed than the wild progenitors (Koinange et al., 1996). However, the same seedlot when harvested usually contains seeds of widely varying size and quality, due to plant genetic variation, inter-plant competition, diseases, and inflorescence location that reflects differences in flowering times and nutrition of the developing seeds (Wood et al., 1977). The use of larger seed of a seed stock usually results in increased germination, speedier emergence, and improved seedling growth (Wood et al., 1977). Comparisons within the same bean cultivar have shown that large seed had higher and faster germination (Marcos Filho and Avancine, 1983) and produced plants with increased shoot and root growth in the field (Perin et al., 2002). Moreover, seed reserves influence plant nutritional efficiency: shoot growth and P uptake of bean genotypes grown under low P supply were positively correlated with their seed mass (Yan et al., 1995), and bean plants originating from seeds with low P concentration showed poorer growth and nodulation as compared to plants originating from high P seeds (Teixeira et al., 1999).

However, studies comparing common bean genotypes of different seed sizes indicated a negative relationship between seed mass and grain yield (Laing et al., 1984; White and González, 1990; White et al., 1992; Sexton et al., 1994). Large-seeded bean genotypes also presented reduced overall plant growth (White et al., 1992) and lower leaf carbon exchange rates (Sexton et al., 1997). White and González (1990) delineated three broad hypotheses which might explain this negative association in common bean: the small seed, or a closely linked characteristic such as cell size, is associated with greater physiological efficiency; large seeds require a greater seed-filling rate or duration of filling; and there is no physiological reason why yield should vary with seed size. Moreover, these differences in yield potential between large- and small-seeded bean genotypes may be a function of cultivar adaptation associated with the region of domestication (Sexton et al., 1994), since small-seeded genotypes were domesticated in a Mesoamerican center while large-seeded genotypes are predominately of Andean origin (Gepts et al., 1986).

Current methods of seed grading and processing remove non-viable seed and select for uniform shape and size. Seed uniformity improves the precision of mechanical drilling and often results in more homogeneous stands (Krzyzanowski et al., 1991). Superior yield performance of large seed of the same bean cultivar would implicate in grading out small seed by seed producers or by farmers themselves, thus affecting the seed market. Therefore, one should distinguish the effects of seed size among bean cultivars of different seed sizes, which can be associated with the physiological adaptation of distinct gene pools, from the effects of the seed size within the same cultivar.

This investigation had the objective of evaluating the effects of sowing different seed sizes of the same cultivar on biomass accumulation and grain yield of common bean cultivars of different seed sizes.

\section{MATERIAL AND METHODS}

The field experiment was carried out at the National Research Center for Agrobiology (Embrapa Agrobiologia),

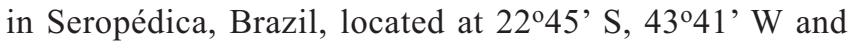
$40 \mathrm{~m}$ of altitude, from May to August 2002. The soil was a Typic Haplustult, presenting at $0-20 \mathrm{~cm}$ depth: water $\mathrm{pH} 5.0,19 \mathrm{mmol}_{\mathrm{c}} \cdot \mathrm{kg}^{-1}$ of $\mathrm{Ca}, 15 \mathrm{mmol}_{\mathrm{c}} \cdot \mathrm{kg}^{-1}$ of $\mathrm{Mg}, 1.8$ $\mathrm{mmol}_{\mathrm{c}} \cdot \mathrm{kg}^{-1}$ of $\mathrm{K}, 1 \mathrm{mmol}_{\mathrm{c}} \cdot \mathrm{kg}^{-1}$ of Al, $12 \mathrm{mmol}_{\mathrm{c}} \cdot \mathrm{kg}^{-1}$ of $\mathrm{H}$, $3 \mathrm{mg} . \mathrm{kg}^{-1}$ of available P, $6.9 \mathrm{~g} . \mathrm{kg}^{-1}$ of organic C, sandy clay loam texture. A $6 \times 2$ split-plot factorial design in four complete randomized blocks was employed, comprising six bean cultivars as the main plots and two seed sizes (small or large) as the subplots (table 1). The cultivars had different growth habits and seed sizes but similar growth cycles. Seeds were manually separated by their size from the same seed stock; large seeds were almost twice as heavy as small seeds of the same cultivar (table 1). Three samples of 50 seeds of each cultivar and seed size were folded into wet paper and placed in a germination chamber at $25^{\circ} \mathrm{C}$; the percentage of germination was determined nine days later. 
Table 1. Some characteristics of the cultivars and seeds used in the experiment

\begin{tabular}{|c|c|c|c|c|c|c|}
\hline \multirow{2}{*}{ Cultivar } & \multirow{2}{*}{$\begin{array}{l}\text { Growth } \\
\text { habit }{ }^{a}\end{array}$} & \multicolumn{2}{|c|}{100 -seed mass $(\mathrm{g})$} & \multirow{2}{*}{$\begin{array}{l}\text { Percent seed } \\
\text { germination }^{c}\end{array}$} & Flowering & Harvest \\
\hline & & $\mathrm{SS}^{\mathrm{b}}$ & LS & & \multicolumn{2}{|c|}{ (days after emergence) } \\
\hline Iraí & I & 27 & 58 & $94 \mathrm{a}$ & 26 & 71 \\
\hline Manteigão & II & 27 & 59 & $94 \mathrm{a}$ & 28 & 71 \\
\hline Carioca & III & 14 & 27 & $93 \mathrm{ab}$ & 39 & 74 \\
\hline Puebla 152 & III & 16 & 32 & $89 \mathrm{c}$ & 40 & 78 \\
\hline Guapo Brilhante & II & 12 & 23 & $90 \mathrm{bc}$ & 33 & 74 \\
\hline Rio Tibagi & II & 11 & 20 & $92 a b c$ & 38 & 78 \\
\hline
\end{tabular}

${ }^{a}$ Growth habit: I erect determinate, II erect indeterminate, III prostrate indeterminate. ${ }^{b}$ SS: small seed, LS: large seed. ${ }^{\mathrm{c}}$ Means of small and large seed, since there was no effect of seed size on germination; means followed by the same letter did not differ by the Tukey test at the 0.05 level.

Each field subplot had eight rows $5 \mathrm{~m}$ long and $0.5 \mathrm{~m}$ apart. Fertilizer was applied to rows at the rate of $2.5 \mathrm{~g} . \mathrm{m}^{-2}$ of $\mathrm{N}, 4.0 \mathrm{~g} . \mathrm{m}^{-2}$ of P and $4.0 \mathrm{~g} \cdot \mathrm{m}^{-2}$ of K. The sowing density was 12 seed. $\mathrm{m}^{-1}$. No additional $\mathrm{N}$ was supplied to the crop since green manure with Crotalaria juncea had been incorporated into the soil two months before planting. At 20 days after emergence (DAE), 0.5 L.ha-1 of herbicide was applied to control weeds. The experiment was irrigated almost weekly. Climatic conditions during the experiment were: mean temperature $21.2^{\circ} \mathrm{C}$, relative humidity $70 \%$, pan evaporation $3.1 \mathrm{~mm}^{\text {day }}{ }^{-1}$, solar radiation 6.9 h.day $^{-1}$.

Crop biomass was sampled weekly at eight growth stages, from 19 to 68 DAE. The sample unit consisted of $0.5 \mathrm{~m}$ of plants harvested from the second or the seventh lines of each subplot. Shoots were harvested at the ground level, and roots were removed by hoeing. Leaflets were counted and detached for photoelectric measurement of leaf area ( $\mathrm{Li}-$ Cor 3100). Leaves, stems, pods, and roots were separately dried and weighed. Data were transformed to biomass per land area and leaf area index (LAI), and values further transformed to natural logarithms in order to homogenise the variances of different sampling dates, as discussed by Araújo (2003). Data of leaf mass and LAI at 68 DAE and of pod mass at 40 DAE were discarded in statistical analysis due to their abnormal variance, but they were included in total plant mass. The analysis of variance was performed considering the effects of cultivar, seed size (as subplot), sampling date (as sub-subplot), and their interactions (Araújo, 2003). The significance of treatment $\times$ harvest interaction for natural logarithmic transformed data indicated differences in relative growth rates (Poorter and Lewis, 1986; Araújo, 2003). Further, the sum of squares was rearranged to perform contrasts between seed sizes (one degree of freedom F test) within each sampling date. Data of total mass and LAI were fitted over time using the second degree exponential polynomial model, and instantaneous values of growth rates were calculated by differentiation of these functions (Hunt, 1982). Leaf area duration was calculated by integrating LAI curves estimated by the second degree exponential polynomial between 19 and $61 \mathrm{DAE}$.

At grain maturity of each cultivar (table 1), $1 \mathrm{~m}^{2}$ from the two middle rows of each plot was harvested at ground level. Plants and pods were counted, pods were threshed, seeds were counted and seeds weighed to provide grain yield. Grain yield from the remaining $3 \mathrm{~m}^{2}$ of the two middle rows of each plot was also measured. Stems, pod walls and seeds were dried and weighed. Seed yield was standardized to $13 \%$ moisture. Yield components and harvest index (ratio between seed and above ground dry mass) were calculated for each subplot. The analysis of variance was performed considering the effects of cultivar, seed size (as subplot) and their interaction, and means of cultivars were compared by the Tukey test at the 0.05 probability level.

\section{RESULTS}

Seed germination was not affected by seed size within cultivars (table 1). Hence, the effects of seed size presented hereafter are not accounted for by differences in seed germination. However, seeds of cultivars Iraí and Manteigão germinated better than those of cultivars Guapo Brilhante and Puebla 152 (table 1).

Considering the average of the six cultivars, plants originating from large seed had higher stem mass than plants originating from small seed during the whole growth cycle (table 2). Large seeds increased leaf, root and total mass of bean plants between 19 and 47 days after emergence (DAE), and they also increased root and total mass at 68 DAE. Plants 
originating from large seed had higher stem:leaf mass ratio than plants from small seed ( 0.51 and 0.47 g.g ${ }^{-1}$, respectively, pooled across eight sampling times). Pod mass was not affected by the planted seed size (table 2).

The effects of seed size on plant growth differed among bean cultivars (figure 1). For cultivars Iraí and Guapo
Brilhante, total plant mass was increased by large seed during almost the whole growth cycle. For cultivars Carioca and Manteigão, large seed increased biomass accumulation only between 19 and 33 DAE, and for Rio Tibagi between 19 and 33 DAE and at 54 DAE. For cultivar Puebla 152, total plant mass was increased by large seed only at 19 DAE (figure 1).

Table 2. Stem, leaf, pod, root and total mass of common bean plants originating from small or large seed at eight times of sampling (means of original data of six bean cultivars and four replicates; data were transformed to logarithms prior to analysis of variance)

\begin{tabular}{|c|c|c|c|c|c|c|c|c|c|c|}
\hline \multirow{2}{*}{$\begin{array}{l}\text { Days after } \\
\text { emergence }\end{array}$} & \multicolumn{2}{|c|}{ Stem mass $\left(\mathrm{g} \cdot \mathrm{m}^{-2}\right)$} & \multicolumn{2}{|c|}{ Leaf mass (g.m $\left.{ }^{-2}\right)$} & \multicolumn{2}{|c|}{ Pod mass (g.m $\left.{ }^{-2}\right)$} & \multicolumn{2}{|c|}{ Root mass (g.m $\left.{ }^{-2}\right)$} & \multicolumn{2}{|c|}{ Total mass (g.m-2) } \\
\hline & $\mathrm{SS}^{\mathrm{a}}$ & LS & SS & LS & SS & LS & SS & LS & SS & LS \\
\hline 19 & 6 & $10^{*}$ & 21 & $31 *$ & - & - & 3.6 & $5.5^{*}$ & 31 & $47^{*}$ \\
\hline 26 & 16 & $23^{*}$ & 43 & $57^{*}$ & - & - & 5.1 & $7.3^{*}$ & 64 & $88^{*}$ \\
\hline 33 & 29 & $41^{*}$ & 61 & $81^{*}$ & - & - & 8.7 & $11.6^{*}$ & 99 & $134^{*}$ \\
\hline 40 & 37 & $51^{*}$ & 76 & $89 *$ & 4 & 3 & 10.5 & $13.0^{*}$ & 127 & $156^{*}$ \\
\hline 47 & 60 & $79 *$ & 100 & $119^{*}$ & 24 & 22 & 11.4 & $14.5^{*}$ & 195 & $234^{*}$ \\
\hline 54 & 65 & $75^{*}$ & 100 & 100 & 61 & 58 & 13.1 & 13.9 & 239 & 247 \\
\hline 61 & 66 & $75^{*}$ & 88 & 87 & 121 & 119 & 11.6 & 12.4 & 286 & 294 \\
\hline 68 & 50 & $67 *$ & 21 & 19 & 146 & 166 & 8.4 & $10.3^{*}$ & 225 & $262 *$ \\
\hline
\end{tabular}

a SS: small seed, LS: large seed. * Significant difference between seed sizes by the F test at the 0.05 level.

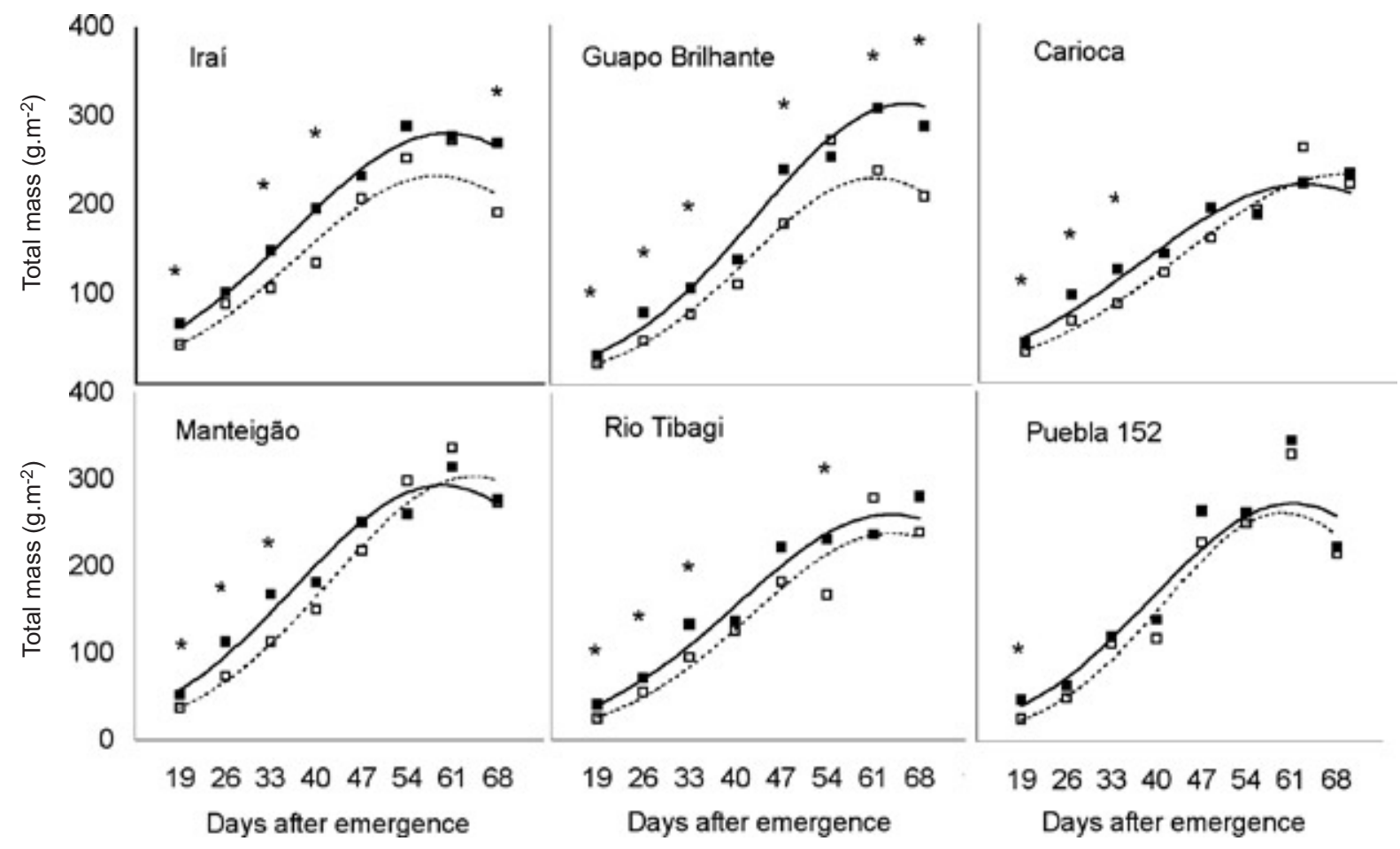

Figure 1. Total mass of six common bean cultivars originating from small ( $\square$ ) or large ( $\square$ ) seed, at eight times of sampling; squares represent experimental means, lines represent the second degree exponential polynomial model adjusted to primary data, and asterisks indicate significant difference between seed sizes within each sampling date by the F test at the 0.05 level performed on natural logarithmic transformed data. 
Large seed increased leaf area production of bean plants, particularly at the beginning of the growth cycle, but this effect varied with the cultivar (figure 2). For cultivars Iraí and Guapo Brilhante, large seed increased the leaf area index (LAI) between 19 and 47 DAE, whereas for Manteigão and Rio Tibagi this effect occurred between 19 and 33 DAE. For cultivar Carioca, LAI of plants originating from large seed was higher between 26 and $33 \mathrm{DAE}$, and for Puebla 152 only at 19 DAE (figure 2). Large seed increased LAI mainly via a greater number of leaves and a larger leaf area per leaf, whereas the specific leaf area was unaffected by seed size (data not presented). Large seed enhanced the leaf area duration for every cultivar (table 3). Bean plants originating from large seed presented higher maximum LAI than plants originating from small seed except for cultivar Puebla 152. The maximum LAI was reached sooner in plants originating from large seed for every cultivar (table 3), indicating that small seed delayed leaf senescence.

Regardless of difficulties for statistical comparison of the growth rates estimated by growth analysis (Araújo, 2003), the significant interaction between seed size and sampling date for natural logarithmic transformed data of total plant biomass indicates that bean plants originating from small seed had a higher relative growth rate than plants originating from large seed (figure 3). Crop growth rate was higher in plants originating from large seed at the beginning of the growth cycle, but this effect disappeared after 41 DAE (figure 3). Significant differences in net assimilation rate remain uncertain because this rate includes two primary variables (Araújo, 2003), but since small seed reduced total mass less than LAI (figures 1 and 2), it is assumed that plants originating from small seed had a higher net assimilation rate than plants from large seed (figure 3).

Cultivars Iraí and Manteigão showed higher grain yield, that can be associated with their greater 100 -seed mass, since they presented a lower number of pods per plant and a lower number of seeds per pod than the other cultivars (table 4). Puebla 152 and Guapo Brilhante had the lowest number of plants at maturity (table 4), reflecting their inferior seed germination (table 1). Cultivars Iraí, Manteigão and Carioca presented a higher mean harvest index than Puebla 152 and Rio Tibagi (table 4).

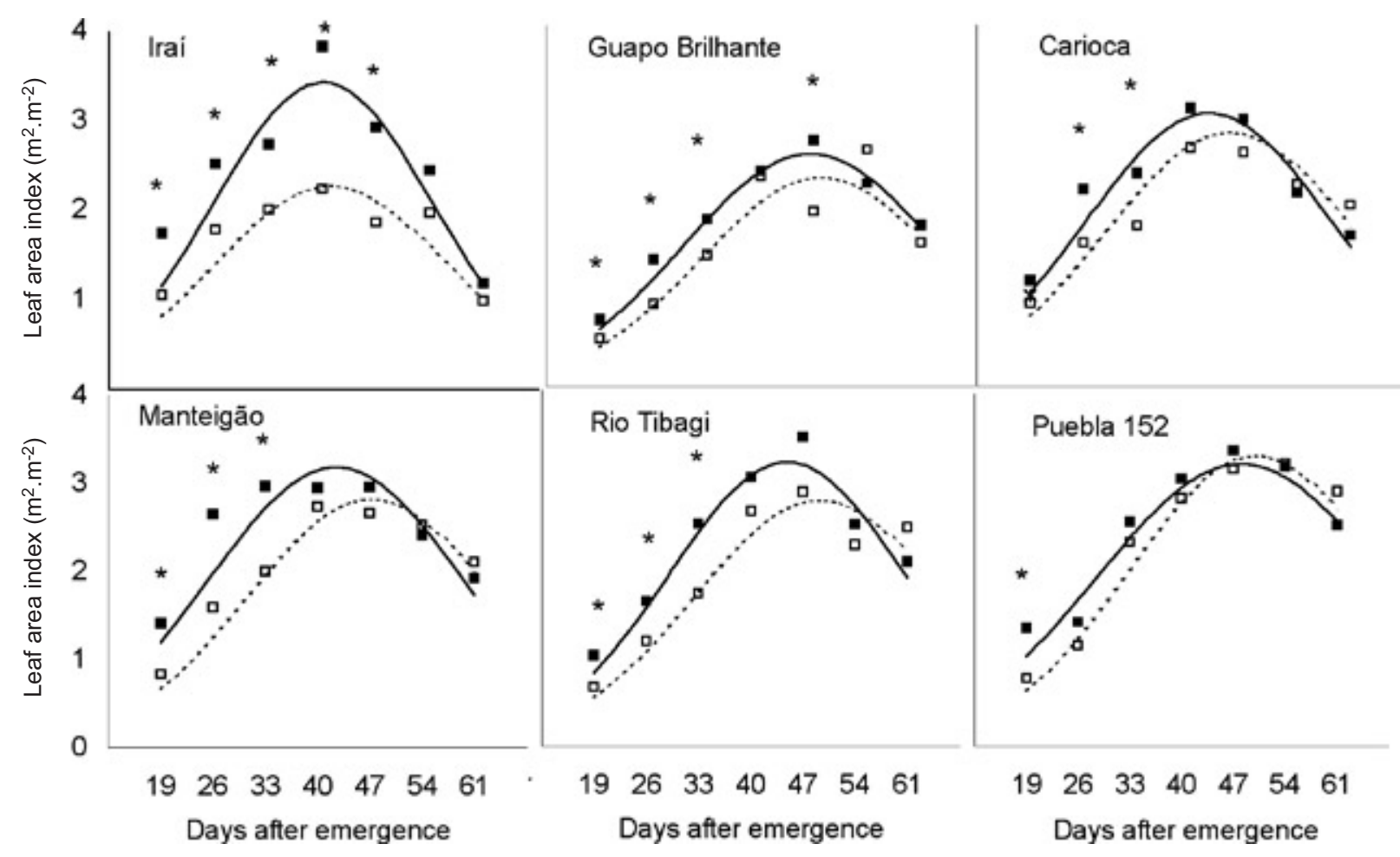

Figure 2. Leaf area index of six common bean cultivars originating from small ( $\square$ ) or large ( $\square$ ) seed, at seven times of sampling; squares represent experimental means, lines represent the second degree exponential polynomial model adjusted to primary data, and asterisks indicate significant difference between seed sizes within each sampling date by the F test at the 0.05 level performed on natural logarithmic transformed data. 
Seed size did not affect the final stand and the grain yield of bean cultivars but modified yield components in distinct ways (table 4). Plants originating from large seed had lower number of seeds per pod, particularly in cultivars Iraí and Puebla 152, but they had higher 100-seed mass, particularly in cultivars Iraí, Manteigão and Puebla 152 (table 4). Commercial cultivars with high genetic uniformity were employed in this experiment, thus seed size selection prior to sowing was of a phenotypical nature, and larger grains produced by sowing large seed can not be due to a genetic separation of lines with different seed sizes within the same cultivar. Large seed increased the number of pods per plant for cultivar Puebla 152 but reduced this yield component for Guapo Brilhante. Cultivars Iraí, Carioca and Guapo Brilhante had a higher harvest index when originating from small seed (table 4). Actually, plants originating from large seed had greater stem mass at maturity $\left(57 \mathrm{~g} . \mathrm{m}^{-2}\right.$, as compared

Table 3. Leaf area duration, maximum leaf area index, days at maximum leaf area index, and ratio between grain yield and leaf area duration, of six common bean cultivars originating from small or large seed (leaf area duration and maximum leaf area index were estimated from the second degree exponential polynomial model adjusted to data of leaf area index between 19 and 61 days after emergence, hence there are no replicates for statistical analysis)

\begin{tabular}{|c|c|c|c|c|c|c|c|c|}
\hline \multirow{2}{*}{ Cultivar } & \multicolumn{2}{|c|}{ Leaf area duration (day) } & \multicolumn{2}{|c|}{$\begin{array}{l}\text { Maximum leaf area index } \\
\qquad\left(\mathrm{m}^{2} \cdot \mathrm{m}^{-2}\right)\end{array}$} & \multicolumn{2}{|c|}{$\begin{array}{c}\text { Days at maximum leaf } \\
\text { area index }\end{array}$} & \multicolumn{2}{|c|}{$\begin{array}{l}\text { Grain yield/leaf area } \\
\text { duration }\left(\mathrm{g} \cdot \mathrm{m}^{-2} \cdot \text { day }^{-1}\right)\end{array}$} \\
\hline & $\mathrm{SS}^{\mathrm{a}}$ & $\mathrm{LS}$ & SS & LS & $\mathrm{SS}$ & LS & SS & LS \\
\hline Iraí & 73 & 106 & 2.26 & 3.42 & 41 & 40 & 1.86 & 1.08 \\
\hline Manteigão & 89 & 106 & 2.82 & 3.18 & 47 & 43 & 1.63 & 1.41 \\
\hline Carioca & 91 & 99 & 2.80 & 3.02 & 45 & 42 & 1.37 & 1.21 \\
\hline Puebla 152 & 101 & 107 & 3.30 & 3.21 & 50 & 48 & 0.82 & 0.94 \\
\hline Guapo Brilhante & 71 & 83 & 2.31 & 2.58 & 48 & 47 & 1.72 & 1.43 \\
\hline Rio Tibagi & 85 & 102 & 2.76 & 3.19 & 49 & 45 & 1.19 & 1.18 \\
\hline All cultivars & 83 & 99 & 2.61 & 3.05 & 47 & 44 & 1.42 & 1.21 \\
\hline
\end{tabular}

a SS: small seed, LS: large seed.

Table 4. Grain yield, yield components, and harvest index of six common bean cultivars, originating from small or large seed (means of four replicates)

\begin{tabular}{|c|c|c|c|c|c|c|c|c|c|}
\hline \multirow{2}{*}{ Cultivar } & \multicolumn{3}{|c|}{ Grain yield (g.m $\left.{ }^{-2}\right)$} & \multicolumn{3}{|c|}{ Number of plants $\left(\mathrm{m}^{-2}\right)$} & \multicolumn{3}{|c|}{ Number of pods.plant ${ }^{-1}$} \\
\hline & $\mathrm{SS}^{\mathrm{a}}$ & LS & Mean & SS & LS & Mean & SS & LS & Mean \\
\hline Iraí & 137 & 115 & $126 \mathrm{a}$ & 23 & 22 & $23 \mathrm{a}$ & 5.7 & 5.1 & $5.4 \mathrm{~b}$ \\
\hline Manteigão & 146 & 150 & $148 \mathrm{a}$ & 19 & 21 & $20 \mathrm{ab}$ & 5.4 & 4.5 & $4.9 \mathrm{~b}$ \\
\hline Carioca & 127 & 122 & $124 \mathrm{ab}$ & 21 & 22 & $21 \mathrm{ab}$ & 8.6 & 7.7 & $8.2 \mathrm{a}$ \\
\hline Puebla 152 & 84 & 103 & $93 \mathrm{c}$ & 16 & 15 & $16 \mathrm{c}$ & 8.0 & $10.8^{*}$ & $9.4 \mathrm{a}$ \\
\hline Guapo Brilhante & 123 & 120 & $122 \mathrm{abc}$ & 19 & 20 & $19 \mathrm{~b}$ & 11.2 & $8.6^{*}$ & $9.9 \mathrm{a}$ \\
\hline Rio Tibagi & 102 & 121 & $112 \mathrm{bc}$ & 21 & 22 & $22 \mathrm{ab}$ & 8.3 & 8.9 & $8.6 \mathrm{a}$ \\
\hline Mean & 120 & 122 & & 20 & 20 & & 7.9 & 7.6 & \\
\hline
\end{tabular}

\begin{tabular}{|c|c|c|c|c|c|c|c|c|c|}
\hline \multirow{2}{*}{ Cultivar } & \multicolumn{3}{|c|}{ Number of seeds per pod } & \multicolumn{3}{|c|}{ 100-seed mass ( $\mathrm{g}$ ) } & \multicolumn{3}{|c|}{ Harvest index (g. $\left.\mathrm{g}^{-1}\right)$} \\
\hline & SS & LS & Mean & SS & LS & Mean & SS & LS & Mean \\
\hline Irai & 3.1 & $2.8^{*}$ & $2.9 \mathrm{c}$ & 42.0 & $44.6^{*}$ & $43.3 \mathrm{a}$ & 0.63 & $0.55^{*}$ & $0.59 \mathrm{a}$ \\
\hline Manteigão & 3.8 & 3.6 & $3.7 \mathrm{~b}$ & 43.1 & $45.7^{*}$ & $44.4 \mathrm{a}$ & 0.59 & 0.58 & $0.58 \mathrm{a}$ \\
\hline Carioca & 4.5 & 4.3 & $4.4 \mathrm{a}$ & 19.1 & 19.1 & $19.1 \mathrm{bc}$ & 0.61 & $0.56^{*}$ & $0.58 \mathrm{a}$ \\
\hline Puebla 152 & 3.8 & $3.4^{*}$ & $3.6 \mathrm{~b}$ & 18.9 & $22.4^{*}$ & $20.6 \mathrm{~b}$ & 0.50 & 0.52 & $0.51 \mathrm{bc}$ \\
\hline Guapo Brilhante & 4.4 & 4.3 & $4.3 \mathrm{a}$ & 17.5 & 18.0 & $17.7 \mathrm{c}$ & 0.57 & $0.54^{*}$ & $0.55 \mathrm{ab}$ \\
\hline Rio Tibagi & 4.3 & 4.3 & $4.3 \mathrm{a}$ & 13.9 & 14.1 & $14.0 \mathrm{~d}$ & 0.50 & 0.48 & $0.49 \mathrm{c}$ \\
\hline Mean & 4.0 & $3.8^{*}$ & & 25.7 & $27.3^{*}$ & & 0.57 & $0.54 *$ & \\
\hline
\end{tabular}

a SS: small seed, LS: large seed. * Significant difference between seed sizes by the F test at the 0.05 level, calculated for each cultivar only when the cultivar $\times$ seed size interaction was significant in the analysis of variance. Means followed by the same letter within a column did not differ by the Tukey test at the 0.05 level. 
to 49 g.m ${ }^{-2}$ of plants from small seed, averaged across the six cultivars), without improved grain yield, resulting in a lower mean harvest index (table 4).

In spite of the nonstatistically-significant cultivar $\times$ seed size interaction for grain yield, considering each cultivar separately elucidates the results. Cultivars Carioca and Manteigão, which showed effects of seed size on plant growth only at the beginning of the growth cycle (figures 1 and 2), also displayed little effects of seed size on grain yield and yield components (table 4). Cultivar Rio Tibagi, where a seed size effect on plant growth persisted until 54 DAE (figure 1), had grain yield increased $19 \%$ by large seed without modifications on yield components (table 4). For cultivar Guapo Brilhante, large seed improved plant biomass during the whole growth cycle (figure 1), but decreased the number of pods per plant without any effect on grain yield (table 4), indicating that plants originating from small seed compensated their inferior growth by increasing the number of pods.

Cultivars Iraí and Puebla 152 behaved in a more complicated manner. In cultivar Iraí, large seed improved growth and LAI during almost the whole growth cycle (figures 1 and 2) but reduced grain yield by $16 \%$ and the number of seeds per pod (table 4). Cultivar Iraí had the greatest stand, and perhaps the increased growth of plants originating from large seed provoked a strong plant competition, resulting in inferior yield and harvest index (table 4). Cultivar Puebla 152, with the lowest effects of seed size on plant growth (figures 1 and 2), had grain yield increased by $23 \%$ using large seed (table 4). This cultivar presented the smallest stand and yield and the strongest modifications on yield components induced by seed size (table 4). Such complex behaviour of bean cultivars is not surprising, since relationships between biological production and grain yield are difficult to establish for common bean (Stone and Pereira, 1994).

\section{DISCUSSION}

These results suggest that sowing larger seeds of a common bean cultivar can increase the biomass production at the beginning of the growth cycle, but these effects tend to disappear after the beginning of pod filling (near $54 \mathrm{DAE}$ ) for most cultivars (figure 1 and table 2). Stems were the plant organs most affected by seed size, as verified by Perin et al. (2002). Hence, increments of biomass and leaf area caused by large seed were more pronounced in cultivars of erect architecture (Iraí, Manteigão, Guapo Brilhante and Rio Tibagi), which present rigid stems to sustain the uprightness, than in cultivars of prostrate growth habit (Carioca and Puebla 152).
Large seed treatments showed increased LAI at the beginning of the growth cycle and leaf area duration (figure 2 and table 3). However, large seed advanced the maximum LAI and leaf senescence (table 3), and thereby plants originating from small seed reached similar LAI during pod filling (figure 2). Stone and Pereira (1994) verified that the maximum values of LAI in bean lines were reached sooner in treatments which promoted a greater leaf area, probably as a consequence of the early leaf senescence induced by increased plant competition. Nonetheless, a higher initial LAI of plants originating from large seed can bring indirect benefits into a commercial crop, promoting rapid soil cover and reducing weed infestation.

Plants originating from small seed showed a higher relative growth rate and net assimilation rate (figure 3), which could be attributed to higher photosynthetic activity associated with lower self-shading due to their reduced LAI, or to lower respiration losses due to their reduced stem biomass. Comparing 16 bean lines, Sexton et al. (1997) observed that leaf carbon exchange rates were negatively related with seed size at two sites, with such an association appearing to result from thinner leaves with lower apparent photosynthetic activity of large-seeded lines. However, in agreement with Perin et al. (2002), we found no effect of seed size on specific leaf area within the same cultivar, and the higher net assimilation rate of plants originating from small seed can not be associated with the production of thicker leaves. It seems that the lower photosynthesis of large-seeded bean genotypes is likely to be an adaptation to a cooler climate and high altitude of the Andean region from which they were domesticated, rather than an effect of their large seed size (Sexton et al., 1997).

In spite of significant stimulus of large seed on bean growth up to the beginning of pod filling (figure 1), pod mass and grain yield were not affected by seed size (tables 2 and 4). Previous work also verified that although large seeds of a common bean cultivar increased plant growth, they did not affect grain yield (Figueiredo and Vieira, 1970; Marcos Filho and Avancine, 1983; Perin et al., 2002), although Ries (1971) observed that large seed increased seed yield of snap beans by $12 \%$. However, the wider genetic diversity used here compared with such previous studies indicated that grain yield and yield components of some bean cultivars can be affected by varying the size of sown seed (table 4). Cultivars with determinate growth habit like Iraí could be impaired by the increased plant competition induced by large seed, whereas indeterminate prostrate cultivars like Puebla 152 could yield better by sowing large seed irrespective of 

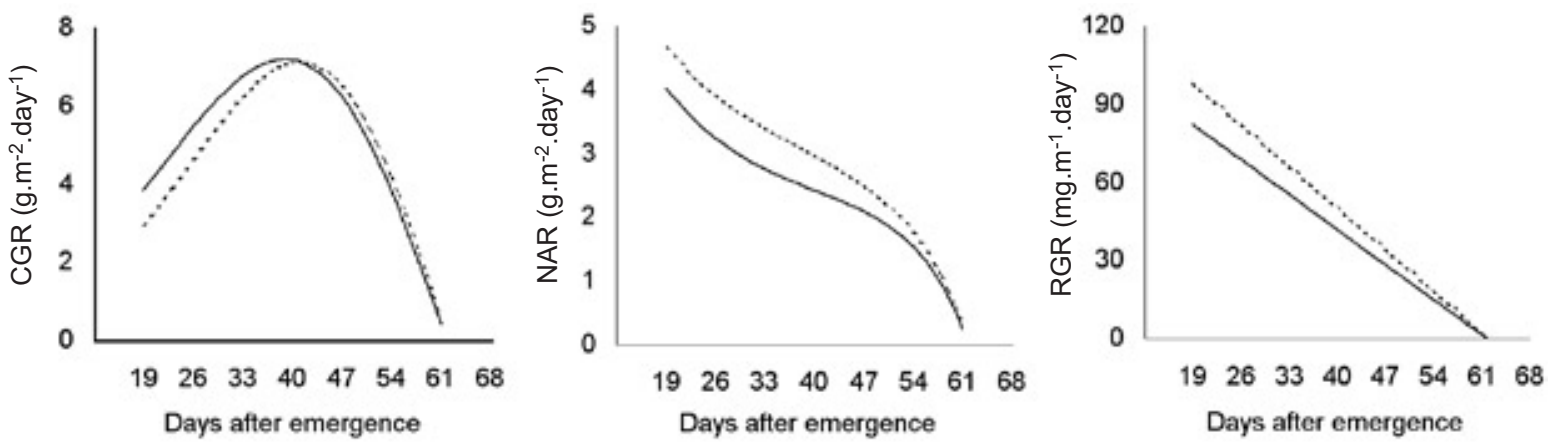

Figure 3. Crop growth rate (CGR), relative growth rate (RGR) and net assimilation rate (NAR) of common bean plants originating from small (------) or large (- seed, estimated by the second degree exponential polynomial model adjusted to primary data of total mass and leaf area index of six cultivars.

the effects upon plant growth, mainly by modifications on yield components (table 4) due to their greater phenotypical plasticity (Kelly et al., 1998).

Wood et al. (1977) postulated that larger seeds are most likely to increase grain yield if the initial growth increase is sufficiently great or when specific yield components are determined during early growth. Since in common bean strong yield component compensation often occurs (Kelly et al., 1998), the initial slower growth of plants originating from small seed would be somehow counterbalanced, by delaying leaf senescence (figure 2), by increasing net assimilation rate (figure 3), or by filling a greater number of seeds per pod (table 4). Laing et al. (1984) observed that cultivars which differ in growth habit and maximum LAI presented a similar ratio between grain yield and leaf area duration, but we verified that plants originating from small seed raised this ratio (table 3), denoting that they converted photosynthates more effectively into grains than plants from large seed. The relatively high correlation between grain yield and harvest index $(\mathrm{r}=0.72, \mathrm{P}<0.01, \mathrm{n}=12)$, as compared to lower values reviewed by Araújo and Teixeira (2003), reinforces that in this experiment biomass partitioning was relatively more important than biological production for grain yield.

Such evidence indicates that the reported negative relationship between seed size and grain yield among bean genotypes (Laing et al., 1984; White and González, 1990; White et al., 1992; Sexton et al., 1994) can not be attributed to the seed size per se, since different seed sizes of the same cultivar did not affect grain yield (Figueiredo and Vieira, 1970; Marcos Filho and Avancine, 1983; Perin et al., 2002; table 4). Therefore, differences in grain yield between largeand small-seeded bean genotypes are likely to be a result of genetic adaptation to the region of domestication of the distinct gene pools (Sexton et al., 1994).
Lack of consistent effects of the sowed seed size on grain yield of a common bean cultivar indicate that the extra costs of grading out small seed and using only the largest seed would not be profitable. Moreover, in species where seeds are covered only by a thin testa as in the case of common bean, seed size closely reflects the amount of reserves, and the small and non-viable seeds are usually discarded during initial cleaning, thus little benefit with regard to germination is achieved by subsequent grading (Wood et al., 1977). However, it is noteworthy that large seed yielded larger grains (table 4), which usually attain a better market price. Additionally, the improved growth induced by large seed may be advantageous for crop establishment under stress environments (as reviewed by Khurana and Singh, 2000) or for reducing weed infestation. Such aspects should also take into account the chosen cultivar and the crop technological level.

\section{REFERENCES}

Araújo AP (2003) Analysis of variance of primary data on plant growth analysis. Pesq. Agrop. Bras. 38:1-10.

Araújo AP, Teixeira MG (2003) Nitrogen and phosphorus harvest indices of common bean cultivars: implications for yield quantity and quality. Plant Soil 257:425-433.

Embrapa (1994) O Cultivo do Feijão: Recomendações Técnicas. Centro Nacional de Pesquisa de Arroz e Feijão, Goiânia, Brazil.

Figueiredo MS, Vieira C (1970) Efeito do tamanho das sementes sôbre o "stand", produção e altura das plantas, na cultura do feijão (Phaseolus vulgaris L.). Rev. Ceres 17:47-60.

Gepts P, Osborn TC, Rashka K, Bliss FA (1986) Phaseolinprotein variability in wild forms and landraces of the common bean (Phaseolus vulgaris): Evidence for multiple centers of domestication. Econ. Bot. 40:451-468.

Graham PH, Ranalli P (1997) Common bean (Phaseolus vulgaris L.). Field Crops Res. 53:131-146.

Hunt R (1982) Plant Growth Curves: The Functional Approach to Plant Growth Analysis. Edward Arnold, London, England. 
Kelly JD, Kolkman JM, Schneider, K (1998) Breeding for yield in dry bean (Phaseolus vulgaris L.). Euphytica 102: 343-356.

Khurana E, Singh JS (2000) Influence of seed size on seedling growth of Albizia procera under different soil water levels. Ann. Bot. 86:1185-1192.

Koinange EMK, Singh SP, Gepts P (1996) Genetic control of the domestication syndrome in common bean. Crop Sci. 36: 1037-1045.

Krzyzanowski FC, França-Neto JB, Costa NP (1991) Efeito da classificação de sementes de soja por tamanho sobre sua qualidade e a precisão de semeadura. Rev. Bras. Sementes 13:59-68.

Laing DR, Jones PG, Davis JHC (1984) Common bean (Phaseolus vulgaris L.). In: Goldsworthy PR, Fisher NM (eds), The Physiology of Tropical Field Crops, pp.305-351. John Wiley, New York, USA.

Marcos Filho J, Avancine F (1983) Tamanho da semente de feijão e desempenho do feijoeiro. Pesq. Agrop. Bras. 18: 1001-1008.

Perin A, Araújo AP, Teixeira MG (2002) Efeito do tamanho da semente na acumulação de biomassa e nutrientes e na produtividade do feijoeiro. Pesq. Agrop. Bras. 37:17111718.

Poorter H, Lewis C (1986) Testing differences in relative growth rate: A method avoiding curve fitting and pairing. Physiol. Plant. 67:223-226.

Ries SK (1971) The relationship of protein content and size of bean seed with growth and yield. J. Am. Soc. Hortic. Sci. 96:557-560.
Sexton PJ, Peterson CM, Boote KJ, White JW (1997) Earlyseason growth in relation to region of domestication, seed size, and leaf traits in common bean. Field Crops Res. 52:69-78.

Sexton PJ, White JW, Boote KJ (1994) Yield-determining processes in relation to cultivar seed size of common bean. Crop Sci. 34:84-91.

Stone LF, Pereira AL (1994) Sucessão arroz-feijão irrigados por aspersão: efeitos de espaçamento entre linhas, adubação e cultivar no crescimento, desenvolvimento radicular e consumo d'água do feijoeiro. Pesq. Agrop. Bras. 29:939-954.

Teixeira MG, Guerra JGM, Almeida DL, Araújo AP, Franco AA (1999) Effect of seed phosphorus concentration on nodulation and growth of three common bean cultivars. J. Plant Nutr. 22:1599-1611.

White JW, González A (1990) Characterization of the negative association between seed yield and seed size among genotypes of common bean. Field Crops Res. 23: 159-175.

White JW, Singh SP, Pino C, Rios BMJ, Buddenhagen I (1992) Effects of seed size and photoperiod response on crop growth and yield of common bean. Field Crops Res. 28:295-307.

Wood DW, Longden PC, Scott RK (1977) Seed size variation; its extent, source and significance in field crops. Seed Sci. Technol. 5:337-352.

Yan X, Lynch, JP, Beebe SE (1995) Genetic variation for phosphorus efficiency of common bean in contrasting soil types: I. Vegetative response. Crop Sci. 35:1086-1093. 